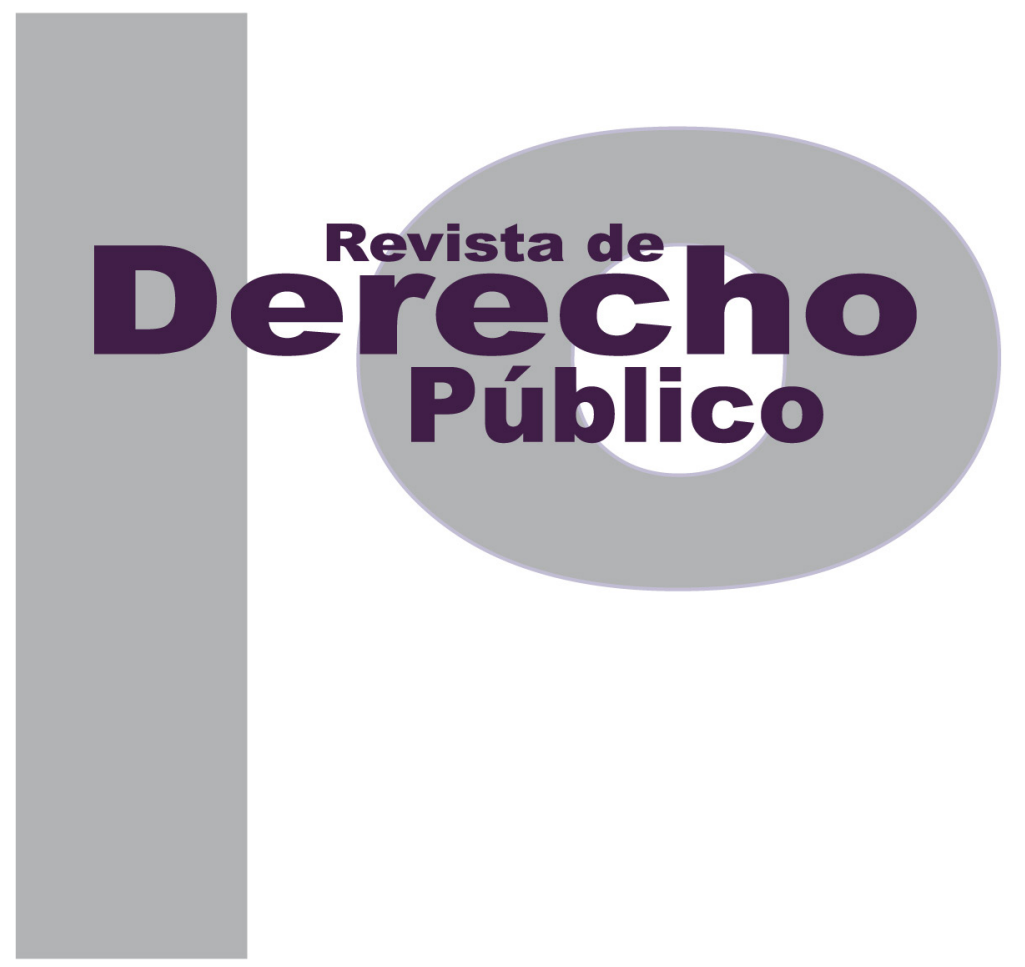

REMINISCENCIAS DE LA VIOLENCIA: EL CASO DEL SUR DEL TOLIMA

\author{
Daniel CAMilo DueÑas
}

Artículo de investigación científica y tecnológica

DOI: http://dx.doi.org/10.15425/redepub.36.2016.11

Universidad de los Andes

Facultad de Derecho

Rev. derecho publico No. 36

enero - junio de 2016. e-ISSN 1909-7778 


\section{Reminiscencias de la violencia: el caso del sur del Tolima}

\section{Resumen}

Se trata de una investigación sobre la construcción de memoria individual y colectiva de una comunidad del sur del Tolima, que fue afectada por el conflicto armado conocido como la Violencia. Se realizaron ocho entrevistas a adultos mayores, cuatro hombres y cuatro mujeres, que contaron aquello que recordaban del periodo en cuestión. Se indagó por la vida de un guerrillero liberal, alias General Arboleda, para conocer cuál era la relación de los líderes liberales con la comunidad, las razones del surgimiento de estos movimientos, la forma en la que actuaron y las relaciones de poder existentes entre diferentes instituciones con los bandoleros. Es un esfuerzo por dignificar aquellos relatos que se quedaron en el ámbito privado de algunas víctimas del conflicto bipartidista. El resultado es un compendio de experiencias y relatos que tuvieron que haber sido tenidos en cuenta por los poderes reconciliados para hacer una transición verdadera a la paz.

Palabras clave: justicia transicional, memoria colectiva, memoria individual, memoria pública, violencia, bandolerismo.

\section{Reminiscences of violence: the case of south Tolima}

\section{Abstract}

This paper is about the construction of the individual as well as collective memory of a community that was affected by la Violencia in the south of Tolima. It is based on eight interviews to senior citizens--four men and four women--that shared their memories of such time. The life of a liberal guerrillero was studied to understand the relationship of liberal leaders with the community, the reasons of the emergence of such movements, their behavior and the power relations between different institutions and the outlaws. This paper is an effort to dignify those stories that remained in the private sphere of some victims of the armed conflict. As such, it is a compendium of experiences and stories that should have been taken into account by the reconciled powers for a real transition to peace.

Key words: transitional justice; collective memory; individual memory; public memory; violence; outlawry.

\section{Reminiscências da violência: o caso do sul do Tolima}

\section{Resumo}

Trata-se de uma pesquisa sobre a construção de memória individual e coletiva de uma comunidade do sul do Tolima, que foi afetada pelo conflito armado conhecido como a Violência. Foram realizadas oito entrevistas a idosos, quatro homens e quatro mulheres, que contaram o que se lembravam do período em questão. Indagou-se pela vida de um guerrilheiro liberal, alcunhado General Arboleda, para conhecer qual era a relação dos líderes liberais com a comunidade, as razões do surgimento destes movimentos, a forma na que atuaram e as relações de poder existentes entre diferentes instituições com os bandoleiros. É um esforço por dignificar estes relatos que ficaram no âmbito privado de algumas vítimas do conflito bi partidarista. 0 resultado é um compêndio de experiências e relatos que tiveram que ter sido levado em consideração pelos poderes reconciliados para fazer uma transição verdadeira para a paz.

Palavras-chave: justiça transicional, memória coletiva, memória individual, memória pública, violência, bandoleirismo. 


\title{
Reminiscencias de la violencia: \\ el caso del sur del Tolima*
}

\author{
Daniel Camilo Dueñas**
}

\section{SUMARIO}

Introducción - I. METODOLOGÍA - II. CÓMO ENTENDER LA MEMORIA - III. REMINISCENCIAS - A. Mataron a Gaitán - B. Huir - C. Los generales - D. Santa Ana - E. Mataron al General Arboleda - IV. CONCLUSIONES - Referencias.

* Cómo citar este artículo: Dueñas, D. C. (Junio, 2016). Reminiscencias de la violencia: el caso del sur del Tolima. Revista de Derecho Público, (36). Universidad de los Andes (Colombia). http://dx.doi.org/10.15425/redepub.36.2016.11

** Politólogo y abogado de la Universidad de los Andes. Correo: dc.duenas147@gmail.com 
Introducción

El mundo occidental, sobre todo después de los grandes conflictos del siglo XX, ha volcado su interés desde varios frentes hacia un campo de estudio antes inexplorado, reconocido como la Memoria. Así, distintas disciplinas (fiIosofía, psicoanálisis, historia, ciencia política, derecho, etc.) han abordado este concepto y han generado sobre él un marco conceptual en donde se unen variados aspectos importantes de la vida humana, como el olvido, la muerte, el ser individual, el ser social, la comunidad, el lenguaje, entre otros. Todos estos elementos se ven concatenados bajo el impulso natural del hombre y de la mujer por recordar y narrar eventos del pasado. Es innegable que la memoria se constituye en un punto esencial de la vida humana, pues su construcción representa en buena medida todos aquellos pulsos o batallas que se libran dentro y fuera del ser (ontológicamente hablando), y que condicionan la manera en la que el individuo o la colectividad entienden y usan su pasado.

El presente proyecto explora la construcción de memoria sobre el fenómeno político y social conocido como la Violencia, pues es un momento de la historia nacional que se escapa a toda acotación y que se podría definir historiográficamente como una anomalía del devenir na- cional (Sánchez, 2003. p. 55). En esa medida, los discursos nacionales y oficiales sobre este periodo no han dado espacio para ejercicios de memoria liderados desde lo público, ${ }^{1}$ lo cual es interesante si tenemos en cuenta que se construyó tácitamente un olvido institucional sobre hechos específicos, víctimas y victimarios. Es decir, aquel conflicto cuenta con pocos registros entendidos como de memoria institucional o pública; ${ }^{2}$ de la misma forma, no fue mucho el aporte de las víctimas a las pocas narraciones oficiales que se generaron sobre el periodo, determinando que los relatos de aquellas personas afectadas por la Violencia se hayan quedado en un espacio predominantemente privado.

Por lo anterior, consideré necesario hacer una caracterización de lo que se entiende por memoria, de la manera en que se ha construido este concepto desde la ciencia, con el fin de generar un marco completo de análisis, desde donde se facilite entender el impacto del término y su respectiva práctica -tanto a nivel privado como público- en el periodo de la Violencia, y más si lo planteado es una recolección de datos que puedan ser observados a partir de la aproximación teórica al término.

Surge entonces una pregunta de investigación que se podría definir de la siguiente forma: ¿Qué narrativas perduran en la memoria co-

1. O muy pocos, destacándose dentro de estos el realizado por la Secretaría de Agricultura de la Gobernación del Tolima, en el año 1959, titulado: La Violencia en el Tolima.

2. Como el surgido desde la Comisión Investigadora de las Causas de la Violencia, que se dice no tuvo gran distribución; aquellos realizados en el Tolima con ayuda de la Gobernación y otras instituciones; los realizados por combatientes, como Cuadernos de campaña, de Manuel Marulanda Vélez; o Balas de la ley, de Alfonso Hilarión, sin contar evidentemente con aquellos surgidos en el mundo de la literatura como La sombra del Sayón, de Augusto Ángel, entre otros. 
lectiva de una comunidad del sur del Tolima afectada por la Violencia?

\section{METOLOGÍA}

Para responder a la pregunta recién planteada realicé una investigación en el eje RioblancoChaparral en el sur del Tolima, por varias razones: primera, esta zona es identificada en el marco teórico como una de las más violentas de ese departamento y del país en el periodo 46-63, por lo mismo fue posible encontrar registros tanto escritos como orales, de situaciones determinables asociadas al conflicto en esta región; segunda, en Chaparral conté con una familia que accedió libre y desinteresadamente a brindarme información sobre hechos que se relacionan con integrantes de su círculo social y sanguíneo; tercera, identifiqué a Luis Efraín Valencia, conocido como General Arboleda, ejemplo de bandolerismo y sobre el cual elaboré un relato que ejemplifica la construcción de memoria individual y colectiva.

Hice una revisión en diarios locales (Tribuna Liberal y El Derecho, ambos de Ibagué) con el fin de establecer la forma en que los medios de comunicación siguieron e informaron las acciones armadas en el sur del Tolima. La razón de dicha revisión documental: clarificar hasta donde fuera posible, con información distinta a aquella que surge de la memoria colectiva o individual, los hechos del período que se estudia en este artículo.

Ahora, el Centro Nacional de Memoria Histórica $(\mathrm{CNMH})$, en variadas publicaciones, acon- seja al investigador usar herramientas de enfoque diferencial en la puesta en marcha de los trabajos de campo, con el fin de mejorar su aproximación a una comunidad que no es homogénea, entendiendo que los hechos víctimizantes no afectan a todos de la misma manera (CNMH, 2015, p. 39), y le permiten hacer un trabajo de memoria incluyente en el que los relatos se inscriben con bases de equidad, reconociendo siempre los acercamientos disímiles de quienes vivieron la experiencia y reconociendo la importancia diferenciada de sus relatos.

El enfoque usado incluyó personas de la tercera edad, por ser ellas quienes vivieron los avatares de la confrontación armada en la década del cincuenta, además es objeto del presente proyecto permitir "a las personas mayores exponer las dinámicas y procesos históricos que han observado del conflicto armado en sus regiones" (CNMH, 2015, p. 47), para alcanzar algunas conclusiones que tengan como base los hechos sujetos de análisis contados por las personas que los experimentaron.

Las entrevistas semiestructuradas intentaron identificar hechos puntuales, como por ejemplo la desmovilización en la finca Santa Ana de guerrilleros liberales. Fueron realizadas a ocho habitantes de Chaparral mayores de 75 años, siete de la zona urbana y uno de la zona rural, incluyendo cuatro hombres y cuatro mujeres con un rango de edad entre los 78 y los 96 años. Las entrevistas fueron transcritas y se encuentran en los anexos de la investigación. 


\section{CÓMO ENTENDER LA MEMORIA}

La memoria existe desde que existe nuestra especie, desde aquellos tiempos en los que no había escritura y todos los conocimientos eran transmitidos de manera oral. Es una herramienta usada desde tiempos sin memoria para la organización de comunidades simples o complejas, para la creación de imaginarios colectivos que generan identidad (Jellin, 2012, p. 43), para la perpetuación de narraciones hegemónicas y, en general, para todo acto humano en donde exista el uso del pasado en el presente.

Pero, ¿cómo podría definirse la memoria? La memoria podría ser entendida como el resultado de la interacción entre los recuerdos o imágenes del mundo exterior y una fuerza como el olvido (Augé, 1998, p. 23). Aquí introduzco un término obligado a la hora de hablar de memoria: el olvido; esta fuerza destructora de recuerdos pero constructora de memoria es el componente vivo del proceso de remembranza (Augé, 1998, p. 20). El olvido se enmarca en una relación binaria fundamental con la memoria, en la que la una no podría existir sin la otra, así como la vida no puede existir sin la muerte.

El olvido guarda una relación indiscutible con los recuerdos, sin él la memoria sería infructuosa en la medida en que se vería saturada por todas las imágenes que nos invaden constantemente en nuestra vida práctica. No todas las imágenes llegan a convertirse en recuer- dos, solo guardamos aquello que se adecúa a una serie de imperativos tanto individuales como sociales.

De hecho, autores como Maurice Halbwachs (1994) sostienen que todos los recuerdos existen en función de marcos sociales construidos alrededor de una comunidad determinada, que la única forma de recuerdo individual es aquella que se produce por medio de los sueños, y que aún en esos casos los sueños se ven influenciados por los comandos establecidos en la comunidad (p. 319); que las imágenes que conservamos están cargadas de ideas que a su vez guardan estrecha relación con nuestra comunidad, con nuestra identidad, y en esa medida la memoria conserva no solo imágenes, sino ideas dominantes que se establecen como hegemónicas (p. 328); que las ideas que guían las imágenes no serán eternas en el tiempo, por el contrario llegan a transformarse (p. 324), y los marcos que estructuran la memoria varían de acuerdo al ingreso de nuevos conceptos que de a poco se van empotrando en el poder; que este proceso contrapone distintas tradiciones que interactúan en una puja constante para que el marco se expanda o contraiga de acuerdo con las necesidades de poder de cada comunidad (339); y que la puja se da básicamente porque una narrativa poderosa confiere beneficios a una tradición comunitaria delimitable (por ende a sus integrantes) y lo anterior sustenta y protege un statu quo en donde hay unos y "otros". 3

3. La palabra hace referencia a aquella construcción social por medio de la cual se establecen diferenciaciones culturales que permiten la creación del "otro", de aquel con el que no se encuentra paralelo y sobre el cual se construye un lenguaje 
Sin embargo, los cambios de narrativa se dan constantemente, surgen en periodos en donde se producen puentes de conversación o lucha frontal entre distintas comunidades y sus narrativas de memoria (Jellin, 2012, p. 59). Así se determina el nacimiento del olvido social, proceso basado en la imposición de una narrativa sobre otra, en el que se establecen nuevos marcos por donde se tiene que mover el individuo en sus procesos de remembranza. Es así como desde una perspectiva social es posible entender la relación de dependencia entre la memoria y el olvido. Una memoria sin olvido es inalcanzable, ya que socialmente las narrativas del pasado y su función en el presente no podrán ser siempre las mismas, debido a que las comunidades y los individuos que las representan cambian con el paso del tiempo. Así, el olvido se convierte en aquello que limpia de a poco los espacios, imágenes o datos de la memoria que no concuerdan con los marcos sociales preestablecidos por la cultura, la comunidad y el lenguaje.

La memoria tiene un componente altamente colectivo; las narraciones del pasado, fruto de las interacciones en la sociedad presente, son en definitiva la estructura de una identidad colectiva y, en esa medida, debatir sobre la singularidad total de lo recordado es una pelea perdida. Ahora, lo que hay que decir es que existe subjetividad inherente al individuo con respecto a la forma en la que recuerda algún hecho sucedido a un número plural de personas, es decir, cada ser individual establece la forma en la que se relaciona con el pasado y el uso que pretende darle en el presente, eso sí, moviéndose siempre dentro de los marcos sociales que dibujan aquellos objetos -ideas e imágenes- (Halbwachs, 1994, p. 327) que pueden ser representados en la narración individual. Sin embargo, las grandes narrativas de los hechos del pasado y los marcos que incluyen las imágenes que se pueden recordar no establecen una única forma de recuerdo; en palabras de Marc Augé:

Me limito a señalar que cada uno de ellos [los objetos: imágenes más ideas] se inserta en un relato que nos implica, porque constituye nuestra versión de los hechos, y porque ocupamos en él un lugar, por más mínimo o pasivo que sea, como miles y millones de otros individuos ocupan su lugar en la versión que elaboran; y poco importa que todas estas versiones estén influidas, moldeadas, a veces casi dictadas por discursos oficiales. (1998, pp. 48-49).

Lo que quiero introducir al debate es precisamente la idea de que los marcos sociales de la memoria no generan una única versión de los hechos, es decir, una memoria "oficial", por el contrario, guían las narrativas individuales por caminos comunes de identidad, por caminos comunes de entendimiento $y$, en general, por caminos comunes de poder preestablecido.

determinista, peyorativo y complejo, que tiene altas cargas de poder simbólico y material. Lo anterior legitima una serie de comportamientos tácitamente aceptados que ocultan narrativas propias de una comunidad entera y establecen comportamientos contrarios a una racionalidad mínima. 
Al respecto, es posible recordar los relatos de memoria y la finalidad que quisieron darle a esa narrativa víctimas del holocausto, como Primo Levi, Jorge Semprún y Jean Améry. Los tres tuvieron el infortunio de vivir en campos de concentración durante la Segunda Guerra Mundial; cada cual representaba identidades distintas: “un judío militante [Améry], un judío a pesar de sí mismo [Levi], y un no judío, militante político de la izquierda francesa y española [Semprún]" (Sánchez, 2008, p. 4). Cada cual representa formas distintas de aproximación al pasado traumático y doloroso; los tres se vieron influenciados por aquellos marcos sociales que afectan narrativas individuales (como lo es ser comunista, o judío militante, en la medida en que se es parte de una comunidad y en ese sentido se obtiene una identidad que transmite información preponderante para la creación de narrativas personales); los tres tienen en común la sombra e influjo de marcos sociales surgidos de los abusos cometidos por el régimen nazi. Por un lado, es posible identificar una variable referente al tiempo que tarda el individuo en contar una experiencia surgida de la remembranza: en el caso de Levi y Améry el proceso fue casi inmediato, a diferencia de Semprún que tardó varias décadas en escribir lo que pudo recordar. Así, es posible decir que el proceso de memoria tiene ritmos distintos (Sánchez, 2008, p. 7). Además, sería acertado afirmar que el olvido cuenta con un procesamiento diferenciado de persona a persona, de acuerdo con el impacto que generó un determinado hecho y de la identidad que se represente en el ser.
Hay otra aproximación a la tesis que expongo sobre subjetividad de relatos. Por un lado tenemos aquellos que se politizan como la de Levi, que entiende la importancia de contar para no repetir, y la de Améry que cuenta para no olvidar, es decir, el ejercicio de memoria no es únicamente el de recordar sino el de usar la información contenida en el relato con fines determinados; al respecto volveré más adelante. Por su parte, Semprún establece por medio del uso de la literatura imaginarios que le permiten comunicar al exterior aquello que es incomunicable, aquello que es imposible de narrar (Sánchez, 2008, p. 7). De esa forma se entiende que la expresión del recuerdo se convierte en una válvula de escape del trauma causado por la experiencia límite, sin embargo esta no es una constante en todas las víctimas del holocausto, algunas sencillamente decidieron olvidar y jamás expresar (pueda que por ningún medio) los vejámenes a las que fueron expuestas. En conclusión, los marcos sociales de la memoria no generan identidades únicas, por el contrario, establecen caminos por medio de los cuales hay transmisión de información básica que permite recrear el pasado apelando a contextos grupales del presente.

En el párrafo anterior introduje una idea que es discutida sobre todo en comunidades que han experimentado transiciones de la guerra a la paz o de la dictadura a la democracia, y es el uso de la memoria en la construcción del presente, es decir, la forma en que la sociedad en su conjunto define recordar los hechos de un pasado tormentoso y la manera en la que 
usa esa información. El tema de memoria es transversal a todas las facetas del ser humano y el estadio público no escapa a las necesidades propias de esta representación social; de hecho se podría decir que el mundo contemporáneo experimenta una creciente aplicación de la "cultura de la memoria" (Jellin, 2012, p. 43), esto gracias a la contraposición entre lo que representa la memoria (como esa nostalgia surgida de una identidad pérdida) y el ritmo de vida desenfrenado, producto de la aplicación de valores capitalistas como la exacerbación del individualismo en función de la producción y el éxito personal, que al final del camino no hace más que transformar la base comunitaria o el tejido social de cualquier comunidad (Sábato, 2011, p. 83). Cada entretejido cultural establece algunas condiciones o marcos que no podrían ser entendidos únicamente en función de la tesis antes expuesta, en la que el capitalismo tiene un rol preponderante en la formación de memoria; el capitalismo sí define una necesidad por la memoria pero no condiciona su existencia, ella existirá siempre y la necesidad y uso variarán con el tiempo. Sobre la memoria pública volveré más adelante.

Tal y como se ha expuesto, la memoria individual se construye a partir de las disposiciones presentes en el tridente sociedad, cultura y lenguaje, generando una narrativa en la que se establece aquello que se puede y aquello se debe recordar en una comunidad. Los marcos sociales de la memoria individual no generan una visión única del hecho, sin embargo esta sí delimita aquellos momentos que deben ser recordados por un grupo social determinable. Aquí se encuentra la importancia de la memoria colectiva, ya que puede ser entendida como una creación social que homogeniza las representaciones individuales o colectivas disimiles del pasado, que suelen tener un componente mitológico muy importante, y sobre las cuales se asienta la identidad colectiva (Aguilar, 2008, p. 50). Es decir, la memoria colectiva parte de un hecho que concuerda con los marcos sociales de la memoria (se puede recordar), que impregna a una serie de individuos integrantes de una comunidad que experimentaron el hecho y que con el tiempo transmiten a las nuevas generaciones aquella información que homogeniza los relatos disonantes en función de una identidad imaginada (Aguilar, 2008, p. 50). La memoria colectiva construye lazos que incluyen a la mayoría de los integrantes de una comunidad en un relato, que aun cuando no hayan vivido el hecho central de este se sienten incluidos pues recae y crea su propia identidad. ${ }^{4}$

Ahora, hay un término que suele complejizar los acercamientos a la memoria debido a que genera confusión: memoria histórica. La confusión surge cuando se unen la memoria y la historia en una sola expresión. La memoria se encuentra distanciada de la historia en

4. Un ejemplo puede surgir de mi vida. Aun cuando no tengo en mi memoria aquellos hechos relacionados con el 0 - 5 de aquel afamado partido Colombia vs. Argentina, siento que los relatos me incluyen como colombiano y en esa medida los reproduzco como si los hubiera vivido, puesto que me conecta con un orgullo nacional que fortalece las ideas propias de mi comunidad imaginada. 
términos de aproximación metodológica y de alcance como fuente objetiva de información (Halbawchs, 2004, p. 212). La historia cuenta aquellos hechos que han afectado el devenir de una sociedad con pretensiones de objetividad, no se interesa necesariamente por relatar las historias locales o regionales, pues busca retener "Ios hechos que interesan al conjunto de los ciudadanos o a los ciudadanos miembros de la nación" (Halbawchs, 2004, p. 211). La historia periodiza, mientras que la memoria se construye como un continuo que no genera separaciones claras, por el contrario, trabaja con límites irregulares e inciertos (Halbawchs, 2004, p. 215), y perdurará hasta tanto se pueda transmitir información de un integrante a otro dentro de la comunidad.

Se podría decir que la memoria nacional se contrapone a la memoria colectiva, debido a que ambas trabajan con marcos sociales distintos (Halbawchs, 2004, p. 212). Una colectividad local puede crear narraciones sobre acontecimientos que son importantes solo para ella, mientras que la memoria nacional genera narraciones en las que se busca construir una identidad imaginada de nación, y evidentemente trabaja con marcos sociales más generales. Encontramos pues, que la memoria colectiva puede surgir en comunidades locales o regionales, sin pretensiones más complejas; mientras que la memoria nacional busca incluir a los integrantes de varias comunidades en imaginarios de identidad nacional. La memoria nacional se podrá identificar entonces con la memoria histórica, aun cuando el término "histórica" no sea el más adecuado para expresar el alcance de esta forma de creación de identidad.

Al hablar de memoria nacional o histórica no puedo dejar de mencionar las políticas de memoria, pues estas construyen en buena parte el alcance de las aproximaciones al pasado dentro de una comunidad nacional. Según Aguilar (2008):

Políticas de memoria son todas aquellas iniciativas de carácter público (no necesariamente político) destinadas a difundir o consolidar una determinada interpretación de algún acontecimiento del pasado de gran relevancia para determinados grupos sociales o políticos, o para el conjunto de un país. (P. 53).

Hay que decir que en una comunidad o grupo social no todos cuentan con las herramientas para llevar a cabo políticas de memoria, por el contrario, son pocos los sujetos que tienen la capacidad de difusión que logre empotrar en el imaginario colectivo alguna interpretación del pasado. El Estado se convierte en uno de los pocos actores con capacidad técnica para elevar acontecimientos del pasado por medio de las políticas de memoria.

Los relatos emitidos por medio de las políticas de memoria son dirigidos a un público que reinterpreta su significado y que configura caminos de acercamiento entre aquella narración producida en el ámbito público y aquella que se encuentra inmersa en su privacidad o colectividad cercana (Aguilar, 2008, p. 53). Las 
políticas de memoria emitidas por el Estado pueden ser entendidas como productoras de memorias oficiales, y por esa razón adquieren tanta relevancia. La memoria oficial demuestra la manera en que el Estado ha definido recordar u olvidar -con todas las implicaciones que esta afirmación conlleva-, es decir, las políticas de memoria suponen reconocer, o no, circunstancias que pudieron haber afectado gravemente a comunidades locales o regionales. Por esta razón debe ser reconocida la importancia del pasado y su interpretación por parte de la sociedad civil, exigiendo que se le dé un tratamiento objetivo y responsable, máxime cuando quien lleva a cabo las políticas es el Estado. Ahora, es importante identificar los usos y abusos de la memoria, y es precisamente lo que haré a continuación

La memoria social es una herramienta política que pone en juego realidades tan trascendentales para la sociedad que su utilización ha sido siempre estratégica; el proceso de selección de lo que se puede olvidar y aquello que se recuerda es, al final, un sistema de memoria selectiva que puede llegar a sostener regímenes totalitarios o económicos (Todorov, 2000, p. 12). El abuso de la memoria social pasa por la manipulación de los hechos y relatos del pasado; muchas veces se han establecido instituciones para jamás olvidar y en otras se han generado pactos para olvidarlo todo; la memoria, en estas circunstancias, encuentra tensiones palpables con la búsqueda de verdad y justicia. Un ejemplo usado por Todorov en su libro Los abusos de la memoria me parece pertinente a la hora de hablar de las sociedades que no olvidan: Américo Vespuccio describió que las luchas que se llevaban a cabo entre algunas comunidades indígenas del nuevo mundo se enraizaban en antiquísimos odios que las enfrascaban en disputas sin salida y aparentemente sin razón -es decir no hubo olvido(Todorov, 2000, p. 26). Qué tan bueno o qué tan malo es olvidarlo todo o no olvidar nada, escapa al análisis del presente marco teórico, sin embargo lo que se hace evidente es que las sociedades, de acuerdo a su contexto cultural, definen los parámetros de olvido y memoria sin que esto signifique que el olvido se enfrente a búsquedas, indagaciones y preguntas surgidas en nuevos contextos que bien pueden relacionarse con cambios en los marcos sociales de memoria (Jellin, 2012, p. 63). Ejemplo de esta situación es la España actual, en la que la decisión política concertada de olvido de los hechos ocurridos en la época de Franco se enfrenta a una generación que quiere hacer memoria; de hecho, las narrativas artísticas son muchas (cine, pintura, escultura, etc.), sin que esto signifique un cambio en la perspectiva oficial. Sin embargo, se ha reconocido la importancia de conocer para no repetir y de olvidar pero no de manera total.

Todorov propone dos aproximaciones a la memoria de acuerdo con la forma en que las comunidades o personas construyen y usan las narrativas del pasado: la "literal" y la "ejemplar" (2000, pp. 30-31). La primera reconoce la singularidad universal de los hechos que generaron victimización, es decir, busca elevar a un punto inalcanzable el dolor por el que atravesaron las víctimas de un fenómeno de- 
terminado; no existirá en ese sentido paralelo de ninguna índole, así mismo su narrativa buscará siempre señalar a los victimarios como responsables no sujetos de perdón; en últimas la memoria literal no da espacio al olvido, por el contrario, hace hincapié en la necesidad de recordar la verdad de los hechos dolorosos por siempre. Por su parte, la memoria ejemplar tiene un componente que busca, sin negar la singularidad del hecho pasado, reconocer que aquellos acontecimientos pueden categorizarse en modelos más grandes o generales y desde ahí establecer continuidades con nuevos actores en nuevas circunstancias; se podría decir entonces que "el pasado se convierte por tanto en principio de acción para el presente" (Todorov, 2000, p. 31). Es posible entender a la memoria ejemplar como un ejercicio liberador por cuanto da espacio para el perdón y como un acto político de crítica en el presente, mientras que la memoria literal, al no reconocer la importancia del perdón, puede acarrear consecuencias negativas para aquella sociedad que interpreta así su pasado. Sin embargo, no hay razón para satanizar a aquellos que quieren elevar la memoria literal de un hecho por sobre la ejemplar; esto se entiende desde lo dicho por Améry: "Perdón y olvido forzados mediante presión social son inmorales" (Sánchez, 2008, p. 9).
Cada ser o sociedad experimenta el trauma de manera distinta. En esa medida se puede entender la dificultad de conciliar el perdón con los procesos atemporales de olvido y de creación de narrativa social o personal; lo importante es reconocer que cada conglomerado tiene el derecho legítimo a re-sentir por el tiempo que haga falta aquello que le puede generar dolor y odio. Los resultados no son necesariamente positivos o negativos. Imponer, como bien lo dice Améry, un sentimiento (el perdón) en función de una meta (la reconciliación o la paz) a una persona o a una comunidad carece de toda legitimidad, pues de lograrse se llegaría a una meta engañosa y poco productiva. $^{5}$

Ahora, volviendo al tema anterior, una crítica usualmente realizada a la memoria ejemplar tiene que ver con el peligro de Ilegar a analogías universales y de esta forma hacer desaparecer la identidad única del hecho experimentado por las víctimas (Todorov, 2000, p. 45), sin embargo habría que decir que la idea de generalizar no es inmutable, por el contrario, es limitada. La idea de limitar la generalización parte de una necesidad práctica, debido a que sería imposible generar paralelos con el presente si se pierde de vista la singularidad mínima de un hecho. Con esto quiero decir que una vez se le arrebata la singularidad al hecho

5. Hace poco en nuestro país, la madre de un desaparecido de los llamados falsos positivos se negó a reconocer el perdón que le ofrecieron las fuerzas armadas ante la probada responsabilidad en los hechos en los que asesinaron a su hijo. El perdón ofrecido, como ella lo describe, no fue verdadero sino producto de una orden judicial, lo cual demuestra la falta de sinceridad. Este es un ejemplo que representa la tensión permanente entre perdón y reconciliación, frente a dolores individuales y subjetivos que se enmarcan en la manera en la que se ha afrontado un trauma surgido de la pérdida. Véase: http://www.caracol. com.co/noticias/actualidad/no-fue-un-perdon-sincero-madre-de-victima-de-falso positivo/20150129/nota/2610417.aspx 
límite también se lo despoja de su importancia para el presente, por tanto no se observa en él un fundamento ejemplar surgido de su singularidad misma. En conclusión, concuerdo con la idea propuesta desde la memoria ejemplar, ya que permite hacer un uso racional del pasado por cuanto exhorta a los integrantes de una comunidad a estar "atentos a las situaciones o acontecimientos nuevos, que aunque distintos, son análogos" (Todorov, 2000, p. 58). Desde esa premisa fundamental es posible decir que la memoria y el olvido no solo se enmarcan en procesos preestablecidos por la cultura y el lenguaje, sino que, por el contrario, tienen un fuerte influjo transformador. Por tanto, desde su aplicación de forma ejemplar se puede alcanzar un valor importante para cualquier sociedad: la justicia.

La contraposición entre las comunidades que quieren olvidar en función del futuro y aquellas que no quieren olvidar absolutamente nada demuestra que la memoria es una creación colectiva en la que se enfrentan distintas interpretaciones del pasado, pues se reconoce que esta genera beneficios (Jellin, 2012, p. 75). Basta recordar el ejemplo de la comunidad afro de los Estados Unidos, que usa la verdad irrefutable de tremendos maltratos que tuvieron lugar en el pasado para obtener una serie de beneficios y privilegios -lo cual se aproxima más a una memoria literal que a una ejemplar- (Todorov, 2000, p. 28). Podría decirse que en algunas ocasiones las narrativas públicas dejan por fuera a algunos actores, sobre todo víctimas, arrebatándoles el derecho legítimo de elegir entre uso literal o ejemplar de la memoria, obligándolas así a transmitir su memoria en el ámbito privado, con lo cual no pueden acceder a los beneficios ofrecidos desde la sociedad o el Estado. Según Jellin, los momentos de ruptura generan choques entre actores con experiencias y horizontes distintos, con interpretaciones disímiles del pasado (2012, p. 80). De este modo, las transiciones aseguran un cambio en la memoria colectiva, sin embargo no en todos los casos resultan incluyentes, algunas alejan a un conglomerado de víctimas de sus derechos de memoria pública, en función de una decisión política evidentemente parcializada por cuanto se ignoró a un grupo determinado.

Esto abre una discusión importante sobre la memoria pública y es: ¿Quiénes tienen legitimidad para recordar el pasado?, ¿Serán los vencedores, los vencidos, las víctimas, los victimarios? Lo cierto es que sea cual sea el actor con más poder en su pugna con los otros, no podrán ser ignoradas las narrativas de las víctimas, de lo contrario nunca se superará el trauma causado por el hecho límite (Jellin, 2012, p. 92). Se podría llegar a decir con Jellin (2012, p. 90), citando expresiones guaraníes, que la construcción de las narrativas del pasado deben representar a un nosotros incluyente (ñade) y no un nosotros excluyente (ore), es decir, que los actores que vivieron los hechos son los únicos legitimados para contar lo sucedido, no se puede y no se debe acallar o imponer narrativas distintas a quienes deben -si les parece importante-contar lo sucedido. El pasado debe representar todas las versiones; obviamente la víctima debe ocupar un lugar preponderante en la narrativa, 
por cuanto fue la que sufrió los avatares de la pérdida y del maltrato. Sin embargo, también en función ejemplificadora se tendrían que conocer las razones que llevaron al victimario a realizar las acciones desvaloradas, con el fin de evitar su nueva aparición en el futuro, teniendo mucha precaución en que en los relatos no se usen argumentos justificativos, o si llegan a ser usados que no hagan parte de la narración oficial de un hecho.

Colombia presenta una situación que tiene que ver directamente con lo expuesto en el párrafo anterior, ya que las narrativas oficiales de la Violencia se vieron altamente influenciadas por los victimarios (bandoleros, el bipartidismo, las fuerzas de seguridad del Estado, la Iglesia Católica, etc.), y se estableció un pacto tácito de olvido y silencio, en donde el civil víctima fue deliberadamente apartado. Lo anterior se puede evidenciar con la creación del Frente Nacional como resultado de un pacto de perdón en donde cada partido renunció a ser la víctima/victimario principal (Sánchez, 2003, p. 61), aunque este perdón y olvido permite inferir que se trató más bien de un deseo de no asumir o confrontar las causas sociales del conflicto y en ese sentido se reafirma el poder que decreta el olvido, dejando siempre de lado aquello que debía contar la víctima y su búsqueda de verdad y justicia (Sánchez, 2003, p. 98). El statu quo se sostiene pero se deja de lado "la dimensión moral y el sentido de reparación histórica a los damnificados" (Sánchez,
2003, p. 61), es decir, la solución pública no fue capaz de darle un cierre a la guerra. Por el contrario, el hecho de no reparar y de olvidarlo todo no ha permitido a la sociedad colombiana resolver la guerra que sufre hoy día.

Colombia ha enfrentado numerosos conflictos a lo largo de su historia republicana, y una constante en ese devenir histórico son las amnistías, ${ }^{6}$ entendidas como una ficción jurídica en la que se declara que no hubo comisión de delitos en el transcurso de un conflicto por parte de ningún actor armado. Así, los actores en conflicto, por más violaciones de derechos que pudieron haberle ocasionado a terceros, pueden disfrutar de todos los derechos que se les brindan como ciudadanos (Sánchez, 2003, pp. 38-39). Se reinaugura el pacto social, olvidando de manera reiterada la necesidad de justicia y verdad para las víctimas, pues se cree que la paz es el valor más importante y que para su consecución es válido hacer cualquier cosa. A propósito Sánchez afirma: "Hacer como si las guerras no hubieran existido, en aras de la reconstrucción de la unidad social y política de la nación, ha sido también una forma de perpetuarlas, de negarse a resolverlas" (2003, p. 109). La negativa constante a afrontar las condiciones reales del conflicto ha sido la razón fundamental para que la guerra no termine.

A continuación presentaré el resultado del trabajo de campo realizado en el sur del Tolima, sobre el periodo conocido como la Violencia.

6. En el siglo XIX se concedieron 17 y 9 en lo que llevamos del XX, junto con 63 indultos en los dos siglos. 


\section{REMINISCENCIAS}

El ejercicio de recordar significa adentrarse en un mundo en el que no es sencillo separar la realidad de la ficción. Un mundo en el que los sujetos crean sus propios diálogos, en el que se transforman eventos y en el que, para llevar la pesada carga de la vida, se generan imaginarios sobre valentía, honor, ferocidad o todo lo opuesto, de acuerdo con la manera en la que se haya vivido el pasado. La experiencia personal y las memorias subjetivas de cada individuo se apegan a un libreto, en el que cobran especial importancia la cultura, el lenguaje y el poder, lo que Halbawchs (1994) definió como marcos sociales de la memoria.

Las entrevistas que realicé en el municipio de Chaparral me demostraron, entre otras, que la memoria individual es una facultad inherente a la condición humana; cada individuo tiene la necesidad natural de recordar hechos que le fueron cercanos, con una visión que surge de su experiencia personal y que se transforma de acuerdo con las necesidades propias de su entorno comunitario y social. Así, por ejemplo, algunos entrevistados no hablaron de masacres, ni mucho menos de que ellos las pudieron haber cometido; al indagar más a fondo se encontraron silencios o negaciones sobre hechos en los que pudieron verse involucrados como victimarios. Con el silencio sobreviene una mirada al suelo, un cambio de tema de manera abrupta, y en muchas ocasiones frases que dejan espacio a la interpretación, como el dicho popular: "No hay nada oculto bajo el sol."
Las experiencias de las personas que entrevisté y que vivieron la Violencia son todas distintas, sin embargo, hay líneas fácticas que unen todos los relatos y que me gustaría mencionar. Teniendo en cuenta que es mejor dejar algunos hechos en el anonimato, no usaré nombres propios, sino que relataré lo que muchos ancianos tienen en la memoria de acuerdo con tres perspectivas: la memoria como construcción individual y social, la Violencia y bandolerismo.

\section{A. Mataron a Gaitán}

Aun cuando en la revisión de la literatura y en el marco teórico afirmé que la violencia bipartidista había empezado con la llegada de Mariano Ospina Pérez al poder, las memorias de todos los entrevistados parecen coincidir en que el momento de inicio de la guerra entre liberales y conservadores fue el 9 de abril de 1948. Sánchez y Meertens (2006) recuerdan que en abril del 48 varios líderes comunitarios como Hermógenes Vargas, alias Vencedor, se levantaron en sus regiones en contra del gobierno conservador, exigiendo la salida del presidente (p. 63). De hecho, uno de mis entrevistados recuerda que en Chaparral, el 9 de abril, una vez se supo que Gaitán había sido asesinado en Bogotá, se desató una persecución en contra de las familias conservadoras del municipio:

Sucede que cuando mataron a Gaitán en el año 48, los liberales y los malos seguidores de ellos hicieron una revolución tremenda en la mayor parte de los pueblos empezando por la capital, en estos pueblos entonces, como 
la mayoría eran liberales, iban a las casas y sacaban a los conservadores y los llevaban a un sitio, allá donde era el colegio de las hermanas, allá los encerraron. (Gutiérrez, 2015).

Las personas entrevistas coincidieron en que la muerte de Gaitán desató una serie de eventos violentos, y es posible identificar en sus relatos hechos que concuerdan con la revolución abrileña de la que hablan Sánchez y Meertens (2006). Una de ellas, oriunda de Las Hermosas, corregimiento de Chaparral, en donde está ubicada la vereda La Profunda, lugar en el que Hermógenes Vargas junto a su familia lideró la revolución abrileña, recuerda:

El mismo día en que muere Gaitán mi padre estaba moliendo, eso tenía que llevar cinco cargas de panela el domingo a La Virginia en bestia, y se enciende ese abaleo al otro lado en un punto que Ilaman La Colaria, de un señor Román, eso quedaba bien de frente, y eso tocó parar las bestias porque el abaleo volaba para el otro lado. Virgen bendita, los trabajadores se vinieron del trabajo en cuatro patas y dijeron: "Don Servando nos vamos a hacer detrás de la casa porque oiga ese abaleo y nos van es a matar". Mi mamá se puso a rezar porque ella era de esas viejas católicas. (Rodríguez, 2015).

La revolución abrileña parece ser un punto de memoria común en los relatos, es decir, que en la memoria social es posible identificar el 9 de abril como inicio de la violencia política. Esto por varias razones: antes de la muerte de Gaitán, por lo menos en esta comunidad del
Tolima, no se identifican hechos en los que la razón de violencia o conflicto sea la filiación política, como bien lo dice un señor grandote, con sombrero y muy recio, en una vereda del corregimiento de La Marina: "Yo recuerdo que antes de que mataran a Gaitán si yo era liberal y usted conservador, nos tomábamos una cerveza y nos abrazábamos, después no se podía hacer eso" (Gutiérrez, 2015). La muerte de Gaitán desata una locura generalizada que tiene, tal y como se identificó en el marco teórico, un breve espacio de tranquilidad en el que se recuerda: "Se hicieron arreglos en Bogotá y el muerto al hoyo y el vivo al baile. Los conservadores más tarde cobraron esa" (Gutiérrez, 2015).

Tenemos tres puntos que valen la pena ser mencionados. El primero es que la construcción de memoria colectiva determinó que el 9 de abril se erigiera como el inicio "formal" de las acciones armadas por filiación política, lo cual concuerda con la visión nacional sobre la Violencia, obviamente hay razones estructurales de este conflicto que se pueden remontar a tiempos anteriores. Así lo demuestra el incremento de la lucha social en el campo y las manifestaciones, huelgas, paros, etc., en las ciudades. La memoria social construyó una fecha, que podría ser considerada hoy como memoria histórica, desde la definición de Paloma Aguilar (2008), en la medida en que fue un hecho que impactó a la nación, y que generó una reacción social que permeó la memoria e identidad de la totalidad de los ciudadanos.

El segundo punto tiene que ver con la comprobación de que efectivamente, en el sector de 
La Profunda, el mismo día, o el día en que se conoció la noticia de la muerte de Gaitán, hubo un levantamiento popular y campesino en contra del gobierno conservador de Mariano Ospina Pérez. No se pudo identificar la contraparte de los campesinos insurrectos, pero es probable que se haya tratado de otros campesinos de filiación política conservadora, sin que esto sea una verdad inmutable, es tan solo una conjetura de mi parte.

Por último, el hecho de que Hermógenes Vargas haya liderado un movimiento de campesinos en contra del gobierno de Ospina Pérez, teniendo como única razón e incentivo la muerte del líder del partido con el cual comulgaba, le da más peso y valor académico a la tesis de Sánchez y Meertens (2006) en la que se afirma que el bandolerismo no tiene como único fundamento las condiciones sociales de una comunidad, tal y como expone Hobsbawm (2001); es decir, el caso colombiano podría demostrar que el bandolerismo tiene dentro de su aproximación social una motivación que puede ser política y que escapa de la teorización del bandolerismo social en sentido estricto. En el caso particular se protege a la comunidad no necesariamente de invasores, o de un poder que golpea directamente a miembros de un conglomerado, sino a la idea que surge de una construcción identitaria muy profunda y arraigada como lo fue la filiación política en los siglos XIX y XX.

\section{B. Huir}

Absolutamente todos los entrevistados tuvieron que salir de sus fincas, algunos en una sola ocasión, otros en varias, debido a la persecución que la policía Chulavita, también llamada la Chulavita o Chulavita, ejercía sobre familias liberales en la zona rural de Chaparral y Rioblanco. Por eso es importante recordar por medio de las palabras de los entrevistados cómo y qué significaba huir en la época de la Violencia.

Lo primero sería identificar a partir de los relatos qué era la policía Chulavita, cómo funcionaba y quienes la conformaban. Se dice que la Policía se politizó durante el gobierno de Mariano Ospina Pérez, después de la muerte de Jorge Eliécer Gaitán. Un entrevistado con ascendencia indígena, de bigote frondoso y de modos muy toscos, me dijo en la sala de su casa: “La persecución desde el alto gobierno [empieza con] el mandato de Mariano Ospina Pérez, que fue el que dejó la famosa policía Chulavita que fue conservatizarla toda, para perseguir a los liberales. EI creador de la Chulavita fue Mariano Ospina Pérez. (Martínez, 2015).

Este mismo hombre, adolecido de chikunguña, y que alguna vez fue guerrillero liberal, me contó la forma en que actuaba la Chulavita:

Ellos perseguían a las familias liberales, asesinaban desde los más chicos a los más grandes, iban a las casas y de una vez desde que fueran liberales... siempre iban con un conservador de la región o de algún lado cercano, él era conocedor de los que eran liberales, no daban previo aviso, el previo aviso era que de una vez llegaban a darle. (Martínez, 2015). 
Los relatos comparten el señalamiento de la sevicia de los actos de la Chulavita. Por ejemplo, un par de señoras que decidieron contarme su historia recuerdan la manera en la que dicha policía entró a su casa:

Llegaron y colgaron a mi mamá para que les dijera en dónde estaban los varones, ellos se habían mañaneado en una montaña ahí cerca, entonces cogieron a mi mamá, la colgaron, la chuzaron para que dijera, pero ella no les dijo. Pero la estropearon feo. (...) a la prima la violaron (...) La tuvieron que sacar alzada, la tuvieron que meter en un canasto, para huir. Qué médico, a huir. (Yate, M.T. y Yate, M. I., 2015).

A las mujeres que ese día estaban en la casa se les dio la orden de salir de la zona porque al otro día muy en la madrugada irían a quemar la casa y al que encontraran lo mataban, y así sucedió efectivamente, a las cuatro de la mañana llegaron personajes de la policía Chulavita y quemaron todo; en palabras de otro entrevistado: "Nos fuimos porque nos quemaron todo, hasta el nidito de los pollos, no dejaron una sola casa allá." (García, 2015).

El impacto de este desplazamiento fue evidente, mayorías campesinas se tuvieron que mover a las grandes ciudades debido a la imposibilidad de trabajar en el campo si se era liberal. Zonas extensas con alta producción agrícola detuvieron sus faenas, de hecho uno de los entrevistados me contó: “Eso quedó por allá todo solo. La gente se replegó para acá y otros se fueron para otros lados y esas fincas quedaron abandonadas, las comisiones que entraban encontraban muy poquita gente." (Gutiérrez, 2015).

Esto concuerda con estudios sobre la Violencia en el Tolima, en los que se estima el daño generado por el incremento de campesinos tanto en áreas rurales en paz como en ciudades intermedias tales como Ibagué, extendiéndose el fenómeno de la indigencia y la malnutrición, sumándose la destrucción del núcleo familiar por el cambio abrupto de las condiciones y la calidad de vida (Pineda, 1960, p. 32).

Salir de la finca significaba, en algunos casos, dirigirse a donde sus allegados en el pueblo, sin embargo son constantes los relatos en los que quienes salían tenían que pasar una temporada escondidos en el monte. La existencia de puestos de control en las entradas de los municipios como Chaparral, dirigidos y organizados por la Chulavita, imposibilitaban el ingreso al pueblo si se venía de una zona de conflicto como Las Hermosas. Entrar era un tema de suerte: por cañadas en las horas de la noche en las que no hubiera vigilancia, o tener algún conocido que intercediera ante la policía; esto obligaba a los campesinos a vivir en el monte hasta que el foco de la persecución cambiara.

Una mujer que a los catorce años tuvo que escapar al monte únicamente con la compañía de un perro que se llamaba Tonto, debido a que su familia había sido capturada en la finca cuando entró la Chulavita, me contó cómo fueron esas primeras horas en lo más profundo 
de un bosque húmedo, en las faldas de una montaña que da a un río:

Eso era tarde, después de estar metida en ese monte toda emparamadita, me tocó quitarme la ropa, torcerla y volvérmela a poner, porque yo qué hacía, y eso echaban bala y decían: En donde la encontremos la pelamos. Y yo le pedía a Nuestro Señor todo milagroso que no me fueran a encontrar. (Rodríguez, 2015).

Las familias enteras tenían que escapar de sus inmuebles: "Cada uno cogía a su familia, grandes, pequeños, y hágale pal monte" (Yate, M. I. y Yate, M. T., 2015). En el monte podían durar meses: "Yo creo que ahí, en esa partecita, duramos como cuatro meses. Pero había que no prender candela de día, porque nos llegaban a ver el humo y nos caían" (Yate, M. I. y Yate, M. T., 2015).

Un entrevistado alto, de brazos largos, sin un pelo en la cabeza, llegó a decirme que había durado años en el monte: "Eso nos tocó salir pitaos pal monte. Yo duré como dos años, durmiendo como un animalito" (García, 2015). La situación era muy penosa pues los alimentos eran difíciles de conseguir, "mientras hubo de las fincas se conseguía, pero después sin administración eso se iba acabando, no había nada que ir a coger" (García, 2015). Había dos opciones: llegar de alguna forma al pueblo o quedarse en la zona con la ayuda de los guerrilleros.

Hermógenes Vargas fundó una colonia de exiliados en un lugar estratégico que solo tenía dos entradas, en cada una había "avanzadas" encargadas de proteger y alertar a la comunidad en caso de que llegaran "comisiones" de la policía_Chulavita. Después de un tiempo, y según me relató una persona muy allegada al General Arboleda, los únicos que quedaron fueron los guerrilleros y las familias de estos: “Nosotros estábamos en una casita por allá, en unos rastrojos vírgenes. Nos hacían los guerrilleros unas casitas de platanillo de las mismas baritas del monte, nos hacían camitas y ahí nos metíamos, de noche asábamos carne, ellos venían de noche."

La huida es un punto fundamental del relato de los adultos mayores. Todas las memorias recuerdan las dificultades propias de vivir en esas circunstancias, sin ningún tipo de comodidad y con la zozobra causada por el miedo a las comisiones Chulavitas. Aquí, la memoria recopila aspectos similares para la comunidad, que generaron identidad en su momento; por ejemplo, todos hablan del monte como un lugar difícil y de la guerrilla liberal como un apoyo a las necesidades básicas de las familias. Como consecuencia se construyó sobre la policía Chulavita un imaginario de rechazo encarnado en apodos como: los Chulos, la Chulavita, Ios Godos, Tombos, entre muchos más, y que generan a un "otro".

La víctima responde de forma violenta en términos prácticos y simbólicos ante los que años atrás eran vecinos y amigos. Tal vez ese es un punto de complejidad de este conflicto: el enfrentamiento entre conocidos y amigos. La memoria de estos hechos no sé qué tanto se ha 
transmitido, es decir, las condiciones penosas inherentes a la huida no se enmarcan en relatos actuales de la comunidad, se sabe y conoce que la situación en ese momento fue implacable, pero no se valora su importancia como experiencia irrepetible, de hecho no estoy tan seguro de que estas memorias se transmitan a los más jóvenes. Sobre esto volveré más adelante.

\section{Los generales}

Tuve la fortuna de entrevistar a personas que participaron de manera directa en las guerriIlas liberales del sur del Tolima. Una del bataIlón bajo las órdenes de Hermógenes Vargas, alias Vencedor; otra que militó con Luis Efraín Valencia, alias General Arboleda; y, finalmente, una mujer que acompañó al General Arboleda en su ámbito más privado. Ambos líderes actuaron en regiones distintas: General Arboleda en Las Hermosas y Vencedor en La Profunda. Alcanzaron renombre regional, y sus figuras encarnan construcciones sociales propias de la memoria colectiva, tales como mitos y leyendas. Por esto es importante contar lo que queda de su historia en la memoria de mis entrevistados. Vale decir que aun cuando pude recolectar información sobre Hermógenes Vargas, esta no se compara con la que recibí sobre Luis Efraín Valencia, por lo que el punto central del presente acápite girará en torno a este último.

El lugar de nacimiento de alias General Arboleda es debatido, unos dicen que era de Al- geciras (Huila) y otros que de Tierra Adentro (Cauca). Sus subalternos le decían el Indio, y teniendo en cuenta que la composición racial del Cauca se acerca más a ese apodo, me inclino por decir que era caucano, sin ánimos de emitir una verdad absoluta. Era de extracción humilde, él y su familia eran campesinos, tenían una finca en Las Hermosas, donde se explotaba café y otros productos propios de la zona. Prestó servicio militar, de donde se dice sacó la puntería por la cual era reconocido en todo el departamento. Vivió algún tiempo en el Valle donde montó una cantina, pero volvió años antes de iniciarse la Violencia para casarse, en los años cuarenta, con una mujer que había conocido en un baile en la casa del señor Gregorio Cruz, en la finca Santa Helena. Se dice que tocaba guitarra, tiple y violín. Compró junto con su mujer una finca por mil pesos, ordeñaba en las mañanas reses de la finca de su cuñado y en las tardes se dedicaba a su cafetal. Recién comprada la finca y recién nacido su hijo mayor, se desató la Violencia. Al ver que la situación se puso complicada dijo "que no se iba a dejar matar, -yo tengo que armar gente-, eso armaba gente con escopetas de fisto, eso era chistoso" (Valencia, 2015). Siguiendo su ejemplo de a poco se fueron formando en todo el departamento otros grupos y líderes: en Rioblanco aparecieron los Loaizas, paisas del Quindío muy verracos según los relatos; en La Profunda, Vencedor; en Planadas, Mariachi; etc. La característica común de estas asociaciones campesinas fue su rápido crecimiento y su incremento paulatino de poder militar. Aun cuando el inicio de las operaciones fue precario, a la vuelta de pocos 
meses estos líderes comandaban verdaderos ejércitos con influencia real sobre las poblaciones liberales.

La organización de los comandos era militar, y la idea en un principio era proteger a las familias de las avanzadas de la policía Chulavita. Al respecto recuerda un integrante del comando de General Arboleda:

La organización era de soldados de pelea. Para defender a las familias las organizaban en caletas regadas en las montañas, allá los cuidaban, les llevaban la comida que podían agarrar. La organización era militar, como ver el ejército, ellos tenían grados y tenían su modo de actuar, porque allá había militares, entre ellos Arboleda y Padilla. Y ellos formaron otro comando mixto en Rioblanco llamado El Davis, porque era entre liberales y comunistas. (Martínez, 2015).

Aquí es posible identificar un hecho que me sorprendió al momento de escucharlo, la división entre los Limpios y los Comunes o comunistas, que no se fundamentaba únicamente en la ideología política sino en toda una cantidad de simbolismos y rencillas que determinarían un enfrentamiento posterior entre facciones ideológicamente opuestas y que fue la génesis de una organización militar comunista nacida en 1962: las Fuerzas Armadas Revolucionarias de Colombia (FARC). El comando mixto El Davis, en donde actuaron Arboleda y Mariachi en sus primeros años como insurgentes, se fue diluyendo cuando en 1953 las guerrillas liberales (los Limpios) acuden al llamado de desmovili- zación que hace el gobierno de Rojas, pero de esto hablaré más adelante.

Las descripciones de la personalidad de General Arboleda pasan por la cercanía que cada entrevistado tuvo con él. Encontré observaciones opuestas con respecto a la manera como actuaba con la comunidad. Por un lado me dijeron:

La misma gente lo subió [a General] porque él era muy grande, porque él no dejaba matar la gente, no dejaba matar mujeres ni niños, no dejaba ni robar, que no robaran, el no compartía eso.

(...)

A él le daba mucha lástima con las mujeres, que les mataran sus maridos y quedaran esas pobres familias. Entonces él adoptaba esas familias en casitas, y en eso hacían casitas, ¿cierto? Y mandaban a robar ganado donde hubiera y eso botaban las patas al río, la gente del pueblo nos daba ropa. Con esa ropa que cocían, les mandaban hilo, tijeras para que cortaran piezas de ropa. (Valencia, 2015).

La otra cara de la moneda la expuso una persona que tuvo una experiencia traumática frente a alguna acción de General Arboleda y su comando. Por esta razón voy a ser muy cuidadoso y hago la siguiente salvedad: en este punto muestro los relatos hallados en la comunidad sobre un personaje que permeó la memoria colectiva, y como bien dije en el marco teórico, la existencia de líneas culturales y sociales por donde tiene que transitar la memoria no limitan la creación personal de un evento 
determinado. Esto quiere decir que cada individuo construye su pasado de acuerdo a su experiencia personal, guardando relación con aquellos dictámenes presentes en la cultura y la sociedad, sin que esto signifique un cambio a nivel individual en relación con su percepción de un evento pasado. Este relato se acerca a la forma de memoria de algunas víctimas como Améry, por cuanto los hechos son revividos con un sentimiento que no busca olvidar sino, por el contrario, recalcar siempre la responsabilidad de los victimarios. Sin más, esta es la percepción de una persona del municipio de Chaparral que dice haber sido víctima de General Arboleda.

Según se me cuenta, General Arboleda había discutido con alguno de sus subalternos porque este se negó a cumplir una orden del comando. Así pues, se dispuso a "cobrar" dicha desobediencia a los integrantes de la familia del desertor. Un Día de la Madre, llegó a una casa en Las Hermosas, saqueó las cargas de caña y café recolectadas durante esa semana, todos los enceres propios de una casa del campo y una tienda en la que se vendía de todo un poquito. En voz de la víctima:

Ser tan cobarde este viejo desgraciado [Gral. Arboleda]. Sacarnos a la orilla del río con los brazos así para atrás amarrados con mis tres hermanos, con un lacito me amarró los brazos para atrás y a mis hermanos los amarró a todos con un solo lazo y los jalaban para acá y los hacían caer y los jalaban para allá y los hacían caer, nos amarró de un botalón grande, ahí nos dejó cuando nos sacó a la orilla del río y nos dijo que nos iban a pelar. Ahí fue cuando yo me arrodillé y le dije: Viejo gran malparido, ¿por qué es tan humillativo con las mujeres?, ¿es que usted no es hijo de una mujer?, ¿usted no se acuerda cuando usted iba a donde mi padre a coger panela porque se estaban muriendo de hambre?, ¿por qué es tan pícaro, tan humillativo? Y se carcajeó. - El consuelo que me queda es que la voy a dejar para que se muera de hambre, la dejo sin qué comer y si usted no se va de aquí, yo la pelo y la echo a este río. (Rodríguez, 2015).

Por último, y para sustentar el argumento de la falta de olvido, la persona dice:

Como yo se lo pedí al Señor de rodillas a la orilla del río, el Señor me escuchó: -"Señor yo tengo que verle el fin de a esta familia", que me dé la licencia el Señor, puede ser yo con bordón, pero que me dé la licencia de verle el fin. (Rodríguez, 2015).

Hermógenes Vargas, Vencedor, no aparece en estos relatos en la misma cantidad que General Arboleda debido a que su región de influencia fue La Profunda, un sector muy alejado de la cabecera municipal y de los demás corregimientos, de ahí su nombre y las conjeturas sobre la ubicación del lugar. A continuación los hallazgos.

Vencedor hacía parte de una familia muy extensa -al parecer se trataba de una familia de veinte hermanos-, dedicada al café, a la caña, al ganado. La muerte de Gaitán incentivó a la 
familia Vargas a tomar las armas y levantarse en contra del gobierno de Ospina Pérez. De hecho una de mis entrevistadas afirma que un integrante de la familia Vargas murió unos días después que Gaitán.

Ellos eran primos de nosotros. Ellos empezaron con poquitos, pero yo creo que eran solo Ios García. (...) Eso empezaron a formarse esos grupos, con tío Jorge, a tío Jorge lo mataron después de Gaitán, a los diitas, y apenas lo mataron ahí empezó la revolución más pesada. (Yate, M. I. y Yate, M. T., 2015).

La Profunda constituye el lugar de operaciones de los Vargas y de Vencedor: "Ya hacia el sector de allá, lo que fue La Profunda, ${ }^{7}$ allá estuvieron los Vargas, Comino, Vencedor, crearon sus autodefensas por allá también" (Gutiérrez, 2015).

Vencedor organizó a una comunidad de exiliados liberales en las montañas de La Profunda. Se le otorgaba a cada núcleo familiar, constituido sobre todo por mujeres, un pedazo de tierra en donde cultivaban alimentos y criaban animales. El lugar era protegido por los guerrilleros y los integrantes varones de las casas, se hacían turnos que vigilaban las posibles entradas al lugar y de vez en cuando se hacían incursiones armadas cuando se tenía información de que la policía Chulavita se encontraba cerca del lugar. Al preguntarle a un exguerrille- ro sobre la forma en la que actuaba Vencedor, esto fue lo que me respondió:

No, mejor dicho eso era buena gente, una maravilla, él era muy humanitario, éramos de la misma familia, él era hijo de Jorge Antonio Vargas, que era primo mío. Y a él lo mataron el Viernes de Dolores, del puente para acá en Santa Ana, lo mató la policía. Tenía por ahí unos 50 años. (García, 2015).

Vencedor muere en El Limón, años después de la pacificación impulsada por Rojas Pinilla.

Hablar de este tipo de personajes es adentrarse en un mundo de subjetividades bastante complejo. Por un lado se encuentran relatos de heroísmo, de magnificencia, mientras que en otros prima el odio y el rencor. Los seres humanos representamos dualidades eternas. La construcción del yo social depende de las acciones, sin embargo el hecho de que el Estado haya brindado amnistía a una serie de combatientes en un conflicto que desbordó toda racionalidad, es como dar licencia al olvido institucional y obligar a un olvido social; es convertir al victimario en un nuevo ciudadano y esto genera tensiones evidentes entre los integrantes de una comunidad. Una víctima que tiene que ver a su victimario paseando por la calle de su pueblo, gozando del reconocimiento y respeto generalizado, no ayuda a la construcción de una paz estable y duradera, por el

7. "En el sur del Tolima Hermógenes Vargas, conocido como "General Vencedor", quien fue junto a su padre uno de los más activos protagonistas de la rebelión abrileña de la facción de La Profunda, municipio de Chaparral” (Sánchez y Meertens, 2006, p. 63). 
contrario, genera profundos sentimientos de venganza y rencor, que no se sabe cómo puedan ser exteriorizados.

Los requerimientos de justicia no pueden, ni deben, ser subvalorados en función de un fin último como puede ser la paz. Sin embargo, y muy a pesar de lo que acabo de decir, hay un consenso generalizado entre mis entrevistados sobre la conveniencia de las políticas de amnistía dictadas por Rojas Pinilla. El consenso común es que era necesario terminar el conflicto de alguna forma, y esta es la radiografía de nuestro presente como nación. Son tan impactantes y tan extendidos nuestros conflictos, que la única solución es olvidarlo todo, porque todo fue muy traumático, porque es mejor detener lo que está pasando iya!, porque el impacto de los hechos es insoportable. Como nación no hemos logrado establecer mecanismos para solucionar de raíz tan profundos daños, y continuamos en una constante que según parece no va a terminar pronto.

\section{Santa Ana}

El teniente general Gustavo Rojas Pinilla, a su llegada al poder, propuso la amnistía universal por los hechos generadores de la Violencia. Bajo el lema "Paz, Justicia y Libertad" se hizo un Ilamado a los miles de guerrilleros que combatían en extensas áreas del país para que depusieran las armas a cambio de perdón y olvido de parte del nuevo y pacifista Gobierno Militar. La llegada de Rojas Pinilla respondía, tal y como lo dije en el marco teórico, a la creciente inestabilidad institucional y al recrudecimiento del conflicto bipartidista.

Desde los aviones que días antes bombardeaban zonas de presencia guerrillera, se lanzaban volantes con la propuesta de amnistía para los guerrilleros. Así lo recuerda una entrevistada: "Cuando se arregló la situación fue cuando llegó Rojas Pinilla, que él botó volantes desde aviones para que cesara la violencia" (Valencia, 2015). La amnistía fue bien recibida por miles de guerrilleros del Llano, del Tolima, de Boyacá, etc., que se entregaron al Gobierno y que en su mayoría volvieron a cultivar el campo y a vivir con su familia.

En la hacienda Santa Ana, que había servido de comando y base de operaciones para la policía y posteriormente para el ejército, el jueves 22 de octubre de 1953 se entregaron 148 guerrilleros dirigidos por General Arboleda y por Mariachi. Vencedor, por su parte, se entregó en el corregimiento El Limón, junto con 192 guerrilleros, el 19 de octubre del mismo año. En aquellas entregas se hacía un intercambio, los guerrilleros entregaban sus armas y el ejército entregaba ropas, herramientas de trabajo y un suculento sancocho. "La guerrilla se entregó, les dieron barretones, machetes, ropa, de todo, le sacaron plata que les daban" (Mendoza, 2015).

La entrega de las armas no fue completa, por el contrario, según los relatos: "Nosotros entregamos algunas, no manteníamos desarmados, guardadas bien envueltas en periódicos en unas cosas que llaman enserados" (Valencia, 
2015), "entregaron fusiles un montón de cosas viejas, pero él no entregó nunca lo bueno. Él no entregó la pistola de él, Mariposa tampoco entregó la pistola propia" (Mendoza, 2015). El desarme fue mentiroso, la entrega de las armas se hizo de manera parcial y contribuyó a que el conflicto tomara nuevos rumbos. Un exguerrillero me dijo al respecto lo siguiente:

Después vino otra parte álgida, que fue el nacimiento del bandolerismo, que fueron bandoleros renegados; entre ellos Mariposa, Franqueza, como comandantes. ¿Por qué se les decía que ellos eran bandoleros?, porque ellos se dedicaron fue a robar ganado, sin importar si fueran liberales o conservadores, lo que importaba era que tuvieran plata. Se dedicaron a la delincuencia común. Y ahí el Gobierno llamó a los comandantes que se habían desmovilizado para formar lo que se vino a llamar como la contraguerrilla. Ahí nació la contraguerrilla, Arboleda se metió en eso, le tocó luchar, la misma guerrilla que se había desmovilizado acabaron con los que se habían vuelto bandoleros. (Martínez, 2015).

General Arboleda se convirtió en un colaborador del Gobierno nacional. De hecho, en la revisión de prensa ya citada, él deja entrever en sus peticiones el deseo de ayudar al Gobierno en su lucha contra los reductos guerrilleros que no se desmovilizaron.

De esta desmovilización puedo decir lo siguiente: las instituciones del Gobierno no invirtieron un centavo para conservar la hacienda Santa Ana; no hubo decisión política para que la casa de la hacienda no quedara en ruinas, no se ha hecho, siquiera, el esfuerzo por colocar una placa conmemorativa de aquel suceso tan importante. La memoria histórica en nuestro país no ha valorado correctamente -desde la perspectiva de lo simbólico encarnado en un monumento, tal y como lo afirma Paloma Aguilar (2008) - la importancia de lugares como este en periodos en los que se vio afectada mucha gente, y sobre la cual solo hay un olvido generalizado y terrible. Lo segundo es que la presencia de armas en cualquier comunidad es problemática, debido a que quienes las poseen pueden incurrir en excesos, como relataré a continuación. Por esto es tan importante que el proceso de desarme se haga de manera correcta, es decir, con la entrega total de aquellos artefactos que por su naturaleza pueden causar daño a muchas personas.

Por último, se abre la puerta para generar interrogantes respecto a la importancia de hacer hoy memoria sobre un periodo que evidentemente no se ve incluido en un continuo nacional. Los marcos sociales de nuestra memoria colectiva no le brindan valor a la época de la Violencia. Por esa razón no son importantes en contextos contemporáneos aquellas experiencias límite que tuvieron que ser afrontadas por una mayoría en vastas zonas de nuestro país y que generaron tantas pérdidas y dolor, de ahí que se nos presentan como ajenas, como lejanas. La importancia de indagar sobre estos temas radica en que el ejercicio en sí se constituye en una herramienta que le permite a la víctima exponer su experiencia ante un público respetuoso -yo-, que no ataca la 
veracidad de los hechos sino que escucha $y$, eventualmente, pregunta. Si bien no tiene una función de construcción de un mejor presente, como podría desprenderse de una lectura de Todorov, es un ejercicio que brinda reconocimiento a tantas voces siempre acalladas por las circunstancias. Se trata de una reivindicación a la persona mayor, al valor de la vejez, a la importancia de la experiencia, aun cuando esta no construya un presente valorado por la mayoría.

\section{E. Mataron al General Arboleda}

Algunos desmovilizados como General Arboleda colaboraron con el Gobierno nacional en la persecución de los reductos subversivos que no entregaron las armas en respuesta al llamado de Rojas Pinilla. Esto significó la entrega de la ley y el poder sobre zonas del país a líderes guerrilleros desmovilizados. En el caso de General Arboleda, se le dio control y derecho sobre el corregimiento de Las Hermosas, lugar en el que construyó fincas ganaderas y cafeteras con muy alta producción. Su responsabilidad era reducir a aquellos que no se hubieran desmovilizado y que estuvieran afectando el orden en la zona rural del municipio de Chaparral.

Una vez reducidos los últimos vestigios de bandolerismo, General Arboleda adquirió una importante posición entre los ricos del pueblo. De hecho, su funeral se realizó en la mejor y más nueva funeraria. Al respecto se recuerda: "Me dijo: mamá, busquemos la funeraria San Pablo, que era la pujante, para enterrar a los ri- cos, porque esa funeraria no era para pobres" (Valencia, 2015). Al parecer, General Arboleda había tenido varios problemas con los ganaderos de Las Hermosas porque constantemente se perdían animales que a los pocos días aparecían en sus terrenos. Esto me fue contado de la siguiente forma:

Todo tiene su más, y eso fue lo que le causó la muerte a él. Cuando acabaron con el bandolerismo, quedaron algunos grupitos que eran de él, entonces él los alimentaba para que fueran a coger ganado, entonces se lo traían a él y se lo vendían barato. (Martínez, 2015).

Su actuar, al parecer, fue cavando también su tumba. Sin embargo, como en la creación de estos personajes se entrelaza lo metafísico con lo real, comparto la siguiente historia:

Resulta que disque Arboleda era de Tierra Adentro, Cauca; que disque los había traído el papá de Efraín, el papá de Efraín los trajo seguro muy pequeñitos acá al cañón. (...) Dicen que Arboleda estaba ahí, lo que nunca lo vieron. Claro, el General, que disque estaba rajando leña, pero mire, rajando leña. $Y$ el tipo, claro, era una eminencia, y claro se le hizo raro eso, entonces rajando leña, y que cuando llegó a meterle una azadita para meterle al fogón ese, cuando dice: !Ay, se me perdió el anillo!, él ya lo había buscado entre la leña. En eso vivía mucha gente en Santa Rosa, y gente que iba a hacer consultas, y que iban a jugar dado. Al hombre le gustaba mucho jugar dado y cartas, pues sí señor, 
que entre todo el tropel de gente buscando, como se dice, una aguja en un pajar, tocando y nada allá donde rajo la leña. Cuando disque dijo: "Parece que se le acabó la vida a Efraín Valencia". Era la liga y se le había cumplido el tiempo, eso existe, porque disque allá en Tierra Adentro, Cauca, eso son todos indígenas, con harto peso como místico, remedios curanderos y no sé qué más. Allá le habían hecho la rezada, entonces por eso jugó tanto, no con la verraquera sino con la liga, y eso no es cuento pero eso sí existió, y como que a los 15 días lo mataron. (Mendoza, 2015).

El 30 de octubre del año 74, cuando don Efraín subía a su finca en un caballo negro, al parecer fue interceptado por algunos hombres que le dispararon causándole la muerte. La noche anterior, comenta un entrevistado, se despidió de sus hijos de manera extraña: al mayor le dijo: “Mijo le encargo a su mamá, y manéjese bien con su mamá que usted como que no se está manejando bien con ella, acuérdese que madre hay una sola en el mundo" (Valencia, 2015).

Según algún relato, sobre el cuerpo dejaron un letrero en cartón que decía: “Aquí es dónde usted viene a pagar todas las injusticias que hizo". Murió a los 52 años y sobre el hecho algún viejo escribió la siguiente canción que se toca y canta con un ritmo de corrido:

El día 30 de octubre del año 74,

al sol lo cubrió una nube,

la tierra un asesinato

cayó un valiente guerrero el General Arboleda lo asesinó un traicionero (bis)

muy cerca de su vereda

era el primer comandante, su segundo era Padilla eran la llave más grande que dirigía la guerrilla luchó en la fatal Violencia contra un mandato tirano que nos seguía sin clemencia

los secuaces de Laureano;

el día en que los partidos reconciliaron la paz nos dijo: "Viejos queridos vámonos a trabajar" hoy solo queda la historia del valiente general, la llevan en su memoria (bis) familiares y demás. (Martínez, 2015).

\section{CONCLUSIONES}

Lo primero que diré es que este trabajo significó una linda forma de explorar contextos que por ajenos que fueran lograron impactarme de manera profunda. Las personas que conocí, y a las que les agradezco sinceramente el haberme recibido en sus casas y haber compartido conmigo sus memorias por el simple hecho de que se los solicité, me han hecho comprender que en nuestro país hay muchos a quienes les ha faltado contar, de la manera que les parezca -ya sea un relato literal o uno ejemplificador-, aquellas experiencias que llevan dentro y que les enmarcaron en duras situaciones de las que no tienen certeza y mucho menos asomo de justicia. Hoy valoro francamente los conceptos de justicia y verdad, y entiendo su importancia para el contexto nacional.

Comprendo las dificultades para alcanzar los mencionados valores, pero estoy seguro que frente a experiencias cercanas no podemos 
dejar que se siga pisoteando a las víctimas en nombre de la paz. No debemos, ni podemos imponer más silencios obligados, las consecuencias han sido nefastas para una gran mayoría y todos tenemos la responsabilidad de exigir que aquellos responsables de crímenes en periodos de guerra, cuando menos, cuenten la verdad de lo sucedido y acepten su responsabilidad. Finalmente, algunas conclusiones con respecto a la pregunta de investigación y otros menesteres.

1. Las memorias individuales chocan conforme a las experiencias vividas con respecto a un hecho determinable, o a un personaje que se represente en imágenes del pasado para una comunidad. Esto quiere decir que los sujetos, tal y como lo expuse al hablar de los distintos tipos de relato del pasado, usan su memoria de acuerdo a necesidades determinadas. Así, me fue posible encontrar relatos que se acercaban a lo ejemplificado por Levi y otros que se aproximaban a lo dicho por Améry (citados por Sánchez, 2008). También, encuentro en el silencio o en el olvido una necesidad de aceptación de sí mismo, pues algunos de mis entrevistados probablemente cargaban pesados recuerdos que consideraban mejor dejar en lo más profundo de la mente.

2. Los marcos sociales expuestos por autores como Halwachs (1994) y Augé (1998) son comprobables en varios relatos en donde se hace evidente la existencia de líneas culturales y de poder que encaminan los discursos. Por ejemplo, todos concuerdan en la importancia de la religión católica en la construcción de imaginarios de justicia, según se desprende de que para algunas personas, lo que no haya pagado algún sujeto en la tierra lo pagará ante Dios, etc. Es evidente cómo el poder de las instituciones que habían fallado en resguardar, por ejemplo, la honra, vida y bienes de los ciudadanos durante la Violencia, impone un olvido que para muchos es necesario, pero que esconde a su vez responsabilidades directas que ya no podrán ser valoradas correctamente por nuestra sociedad.

3. La Violencia, tal como lo afirma Sánchez (2003), es un periodo de nuestra historia que no produjo líneas que se hayan extendido a relatos más contemporáneos, es decir, aun cuando se conoce que fue un tiempo de conflicto entre liberales y conservadores, esta no se incluye en un marco general del conflicto armado posterior, por varias razones: primera, la denominación que desde el poder se le dio al conflicto; la Violencia, como nombre, no representa nada, no genera responsabilidades. Desde el lenguaje y el nombramiento de un fenómeno se imponen fuertes formas de poder.

El Estado, al haber sido un directo responsable de las violaciones a los derechos de sus ciudadanos, debió brindar la importancia y el tratamiento requerido por el tema de la Violencia. Por el contrario, usó su poder para invisibilizar a las víctimas y sus requerimientos de justicia y verdad. Por ejemplo, los textos escolares "no logran (o 
no quieren) integrar los conflictos en un relato coherente. Es decir, están separados de sus contextos y los presentan sin ningún tipo de relación, completamente aislados" (Tatjana y Alessandra, 2015, p. 9). El poder de muchas instituciones como la Iglesia católica, la Policía, el Ejército, Ios partidos Conservador y Liberal, facilitó la llegada del silencio y del olvido. De esta forma, las responsabilidades de aquellos que dictaminaron caminos de odio y que intervinieron notoriamente en el conflicto fueron socavadas en función de una paz que no hemos logrado alcanzar.

4. El bandolero, que en este trabajo toma muchos nombres y alias, es un personaje que, como bien lo define Hobswaum (2001), lucha en primer término por su comunidad frente a un poder que les coacciona. Aquellos bandoleros demuestran que el deseo fundamental de sus acciones violentas no era transformar la organización misma de la sociedad, sino repeler los ataques constantes por parte de un poder determinado, que en el caso del sur del Tolima es encarnado por la policía Chulavita, primero, y el ejército, después. La creación de imaginarios sociales tales como mitos, leyendas, canciones, entre otros, pudo evidenciarse en los relatos de los entrevistados, con lo cual es posible afirmar que el fenómeno mundialmente extendido del bandolerismo también se sucedió en Colombia durante el siglo XX. La particularidad del caso colombiano está en que su nacimiento no tuvo como fundamento único la realidad social.
La revolución abrileña en la que participó Vencedor demuestra que la motivación para proteger a una comunidad no es rastreable únicamente en las condiciones de vida de esta, por el contrario, puede tratarse de una reacción propia a una construcción identitaria muy profunda como lo fue, hasta el siglo pasado, la filiación a un partido político tradicional.

5. Al preguntarme por la importancia de hacer este tipo de ejercicios respecto a periodos como el de la Violencia, que no encuentran conexión con la realidad contemporánea del país - no porque exista una distinción real de hechos, sino por la manera en que esta fue invisibilizada en el relato de memoria histórica nacional-, mi hipótesis inicial era que el trabajo no brindaría herramientas para la construcción del presente nacional. Pero una vez realizadas las entrevistas pude reconocer en las personas que me contaban sus vivencias un cambio, si bien no radical sí de semblante: se iluminaban sus rostros con sonrisas y su actitud con buenas maneras, con agradecimientos y nuevas invitaciones. La visibilización de sus sentimientos a través de los relatos y el hecho de ser el centro de atención en una conversación que les permitió reconstruir hechos del pasado, generó en ellas un estado de satisfacción, de gratitud, que exteriorizaron, como ya lo dije, con sonrisas y buenos modos.

La importancia de estos ejercicios radica en que la víctima pueda contar su relato como quiera, construirlo de la forma que considere 
pertinente sin que nadie la interpele con el ániReferencias mo de menoscabar su veracidad, es decir, de una manera que se empodere al relator. Los hechos que me fueron transmitidos aunque no son todos comprobables, sí demuestran construcciones de identidad muy complejas debido a la subjetividad que representan las vivencias de muchos de mis entrevistados.

En la presente investigación busqué crear un relato que pudiera acercarnos a lo complejo e impactante que fue y continúa siendo para las personas que vivieron la Violencia, las experiencias que tuvieron que sufrir. Obviamente cualquier esfuerzo por enmarcar estas vivencias en un texto es bien difícil, sin embargo, el ejercicio estaba dirigido a que quienes lean la presente recopilación de testimonios puedan comprender, someramente, las dificultades que tuvieron que atravesar las mayorías campesinas de una región del sur del Tolima.

Para finalizar, la conclusión más importante: la paz no es un valor que justifique el olvido y mucho menos la falta de justicia y verdad. Las víctimas de periodos de conflicto tienen que ser escuchadas y la memoria nacional tiene que ser construida a partir de aquellas experiencias que no pueden ser repetidas. Este tipo de ejercicios servirá para la construcción de un presente en paz, si como sociedad brindamos la importancia debida a los relatos sobre periodos traumáticos del devenir nacional y nos proponemos evitar a toda costa que las variables que dieron paso a tan terribles patrones de violencia se repitan.

1. Aguilar Fernández, P. (2008). Políticas de la memoria y memoria de la política: el caso español en perspectiva comparada. Madrid: Alianza Editorial.

2. Augé, M. (1998). Las formas del olvido. Barcelona: Gedisa Editorial.

3. Cabrera de Valencia, N. (16 de abril de 2015). Entrevistado por D. C. Dueñas. Chaparral, Tolima.

4. Centro Nacional de Memoria Histórica CNMH. (2015). Memoria histórica en el ámbito territorial: orientaciones para autoridades territoriales. Bogotá: CNMH. Obtenido de centrodememoriahistorica: http://www. centrodememoriahistorica.gov.co/informes.

5. El Derecho: órgano del Directorio Departamental Conservador. (Enero-diciembre, 1950, 1951, 1952, 1953, 1954).

6. García, 0. (16 de abril de 2015). Entrevistado por D. C. Dueñas. Chaparral, Tolima.

7. Gutiérrez, L. A. (16 de abril de 2015). Entrevistado por D. C. Dueñas. Chaparral, Tolima.

8. Halbwachs, M. (1994). Los marcos sociales de la memoria. Barcelona: Anthropos.

9. Halbawchs, M. (Febrero de 2004). Memoria colectiva y memoria histórica. Revista Española de Investigaciones Sociológicas, (69), 209-219. 
10. Hobsbawm, E. (2001). Bandidos. Barcelona: Crítica.

11. Jellin, E. (2012). Los trabajos de la memoria. Lima: Instituto de Estudios Peruanos.

12. Martínez, G. (21 de abril de 2015). Entrevistado por D. C. Dueñas. Chaparral, Tolima.

13. Mendoza, A. (17 de abril de 2015). Entrevistado por D. C. Dueñas. Chaparral, Tolima.

14. Pineda, R. (1960). El impacto de la violencia en el Tolima: el caso de El Líbano. Bogotá: Universidad Nacional de Colombia, Departamento de Sociología.

15. Rodríguez, I. (17 de abril de 2015). Entrevistada por D. C. Dueñas. Chaparral, Tolima.

16. Sábato, E. (2011). La resistencia. Barcelona: Ediciones Seix Barral.

17. Sánchez, G. (1976). 1929, los “Bolcheviques del Líbano". Bogotá: El Mohán Editores.

18. Sánchez, G. (2003). Guerras, memoria e historia. Bogotá: Instituto Colombiano de Antropología e Historia.

19. Sánchez, G. (Mayo-Agosto de 2008). Tiempos de memoria, tiempos de víctimas. Análisis Político, (63), 3-21. Obtenido de revistas.unal: http://www.revistas.unal.
edu.co/index.php/anpol/article/viewFile/46014/47567

20. Sánchez, G. y Meertens, D. (2006). Bandoleros, gamonales y campesinos. Bogotá: Punto de lectura.

21. Secretaría de Agricultura. (1959). La Violencia en Colombia. Ibagué: Gobernación del Tolima.

22. Tatjana, L. y Alessandra, M. (Marzo de 2015). Perspectivas interdisciplinares sobre la memoria. Sextante: Bitácora de la Facultad de Ciencias Sociales, (5). Obtenido de sextante: http://sextante.uniandes. edu.co/index.php/ejemplares/sextante-5/ horizontes/perspectivas-interdisciplinaressobre-la-memoria

23. Todorov, T. (2000). Los abusos de la memoria. Barcelona: Ediciones Paidós Ibérica.

24. Tribuna Liberal: Un diario Liberal al servicio del Tolima. (Julio-noviembre, 1952-1953; noviembre-marzo, 1952-1953; marzo-octubre, 1954).

25. Valencia, N. (16 de abril de 2015). Entrevistada por D. C. Dueñas. Chaparral, Tolima.

26. Yate, M. I. (20 de abril de 2015). Entrevistada por D. C. Dueñas. Chaparral, Tolima.

27. Yate, M. T. (20 de abril de 2015). Entrevistada por D. C. Dueñas. Chaparral, Tolima. 